\title{
暫: 定防錆の一、三の例
}

仕上品の詝藏又は遠距離輸送の場合には仕上面 の腐蝕登錆を防止する第飞從來ダリースを叙抹し てねた。

此の方法はダリース其の物が篎錆の原因となる 如き不純物を混せす中性上質のるのならば尤も簡 單にして確かを方法であらう。

然るイグリースに性往ふ粗惡なるるのありその 第鍇を誘發する惧为ある。

又仕上部分が雨水又は海水等の飛沫をらりる時 山部分的に其の粱抹䇠所が溶損して錆を發生する ととがある。

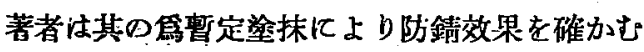
る䉆に 2.3 の被皦を行い之を長時問海水中に放 直して渻飿の如何を調へてみね。

\section{1. 純パラフィンの被覆}

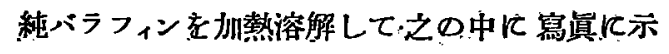
ナタービン異の大小 3 種を浸清して充分翼にピラ フィン附着せしめた。

\section{2. コールドサイズの被覆}

前同様 3 種の翼に布片を以て綿密に染上げを。

\section{渡邊 一 䬦}

之は至極簡單に塗れる。

\section{3. ゼラチン被覆}

ゼラチン溫湯に溶解して筀つてみえが金屬面に 來ら和失敗した。

以上の中 (1) 及 (2)の被覆を存世る，すの 10 月の始めから 5 月の来迄約 230 日闃海水中に浸 清して腐蝕發錩を調へてみた。:

パラフィン及ゴールトサイズ共に完全に被垬せ られた所には毫子腐玲は起つてわなかつを。阙し パランィンは被覆が均一に行かす棱角の部分生附 着展薄く且洜落し易饥。

又少しの震動又は打慗に上りても利落又雅裂を

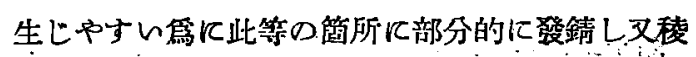

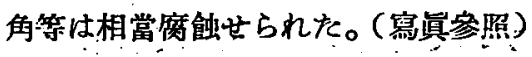

ヌゴールドサズ染布せるものは仕上堂時と

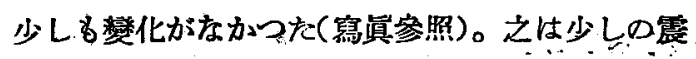
動打撃に因つて虽落しないから被覆としては安全

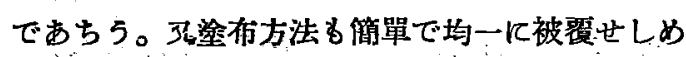
得る故上記の目的には好いといふととが出來る。 


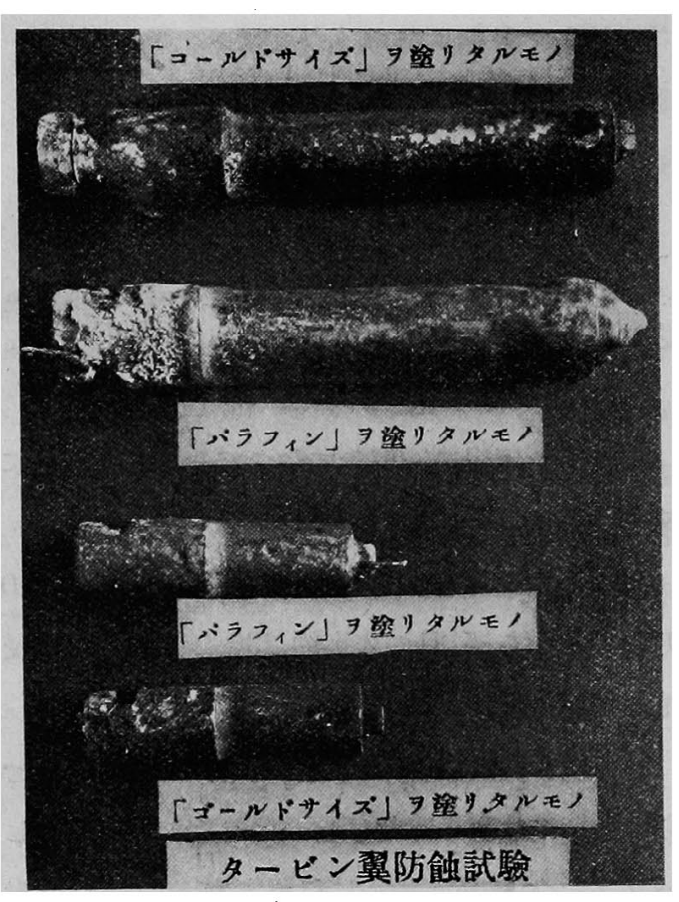

第 1 圆

海水中より引上げたもの

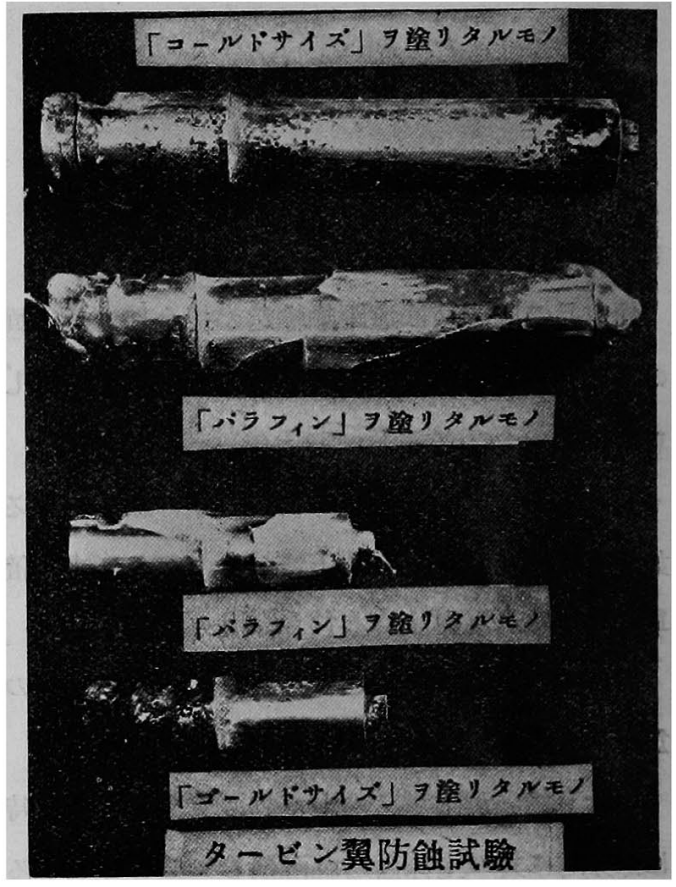

第 2 圖

第1圖の上染の部分を制落し其の鹰蝕の狀況を示才 A ……完全に腐蝕せらず金屬光瀑を有与

B ……部分の少さく腐蝕せられたり

C及D.. 小型の第に完全に染布せら狄たる篇に少し 屯腐蝕せら机ず

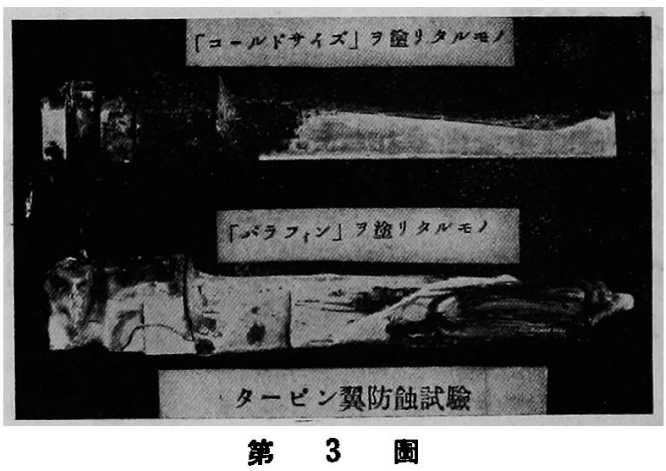

A ・右方側面の金原光澤をなせる所は海水中よ， り引上げ後㾞料を制落せしめたる箇所にて 全く腐蝕せられず

B. 右方侧面の下部稜は全く腐蝕せら机又ネッ クに沂き所黑色をなぜるはハラフィンの膫 目から海水力“浸蝕せる痕跡である。又左方

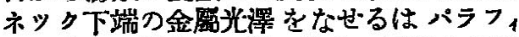

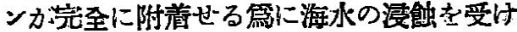
なかつたのである。 